\title{
Priming i framing wybranych polskich publikacji o zamachach terrorystycznych w Brukseli w 2016 roku
}

\section{Wprowadzenie}

Czy współczesny terroryzm stanowi strategię zarządzania mediami masowymi? Czy organizacje terrorystyczne, jako organizacje pozarządowe, stanowią integralny element komunikowania politycznego? Są to ważne pytania, będące przyczynkiem do dyskusji na temat relacji istniejących pomiędzy mediami a terroryzmem, w której uczestniczą medioznawcy, politolodzy, socjolodzy i psycholodzy społeczni. Walter Laqueur zauważa, że klasyczny terroryzm jest propagandą poprzez czyn, a bez zastosowania mediów propaganda byłaby niemożliwa. Zdaniem tego amerykańskiego historyka i publicysty dziennikarze mogą zostać nazwani „najlepszymi przyjaciółmi terrorystów”, ponieważ zwracają uwagę opinii publicznej na ich działalność, nadając rozgłos dokonywanym aktom terroru. Zamachowcy potrzebują mediów, natomiast media znajdują w aktach terroryzmu wszystkie składniki ekscytującej historii i nadmiernie podsycają zainteresowanie nimi opinii publicznej. W niektórych przypadkach środki przekazu nie zachowują proporcji w przekazywaniu informacji i popadają w sensacjonalizm ${ }^{1}$. Laqueur zauważa, że nie wszystkie kraje, w których dokonywane są zamachy, stają się przedmiotem uwagi mediów. Jako przykład przywołuje zainteresowanie dziennikarzy aktami terrorystycznymi, których ofiarami było dwanaście osób w Izraelu w 1985 roku, dwóch brytyjskich żołnierzy zamordowanych w Irlandii Północnej w tym samym roku czy siedmiu Amerykanów zabitych w 1982 roku. Z kolei temat wielu tysięcy ofiar terroryzmu, które poniosły śmierć w Iranie, Iraku, Ugandzie czy Kambodży został przez zachodnioeuropejskie media przemilczany². Bruce Hoffman podkreśla,

* Ks.dr, e-mail: rafalles@vp.pl; Uniwersytet Kardynała Stefana Wyszyńskiego, Instytut Edukacji Medialnej i Dziennikarstwa.

${ }^{1}$ W. Laqueur, The New Terrorism. Fanaticism and the Arms of Mass Destruction, Oxford University Press, New York 2000, s. 43-44.

${ }^{2}$ Tamże, s. 44. 
że zamachowcom zależy, żeby mass media informowały opinię publiczną o ich działaniach - w ten sposób wiadomości o aktach przemocy docierają do większego audytorium, a terroryści mają większą siłę oddziaływania³.

22 marca 2016 roku w Brukseli miała miejsce seria samobójczych zamachów, w których oprócz trzech terrorystów zginęły trzydzieści dwie osoby, a ponad trzysta zostało rannych ${ }^{4}$. Do akcji przyznała się organizacja terrorystyczna Państwo Islamskie ${ }^{5}$. Brukselski akt terroru był kolejną formą przemocy po dwukrotnych atakach w Paryżu w 2015 roku (7 stycznia w siedzibie tygodnika „Charlie Hebdo" oraz 13 listopada), pod którymi podpisała się ISIS.

Autor artykułu zbadał, w jakim stopniu ogólnopolskie dzienniki „Rzeczpospolita” i „Gazeta Wyborcza” realizowały funkcję torowania oraz ramowania w kształtowaniu wizerunku organizacji terrorystycznej Państwo Islamskie po dokonanych zamachach bombowych w marcu 2016 roku. Pozwoliło to na uzyskanie wyważonej oceny, czy i w jakim stopniu zostało zrealizowane przez polskie tytuły prasowe prawo do informacji rozumiane w sensie czynnym (prawo do informowania innych) i biernym (prawo do bycia poinformowanym) ${ }^{6}$; czy dzienniki uległy sensacjonalizmowi (wskutek nadmiernego zwrócenia uwagi opinii publicznej na zamachy) lub może celowo nie poruszyły tematów zamachów w Brukseli.

\section{Metodologia pracy}

Analizowany materiał stanowiły wszystkie teksty, które ukazały się w wersji drukowanej ogólnopolskich dzienników („,Rzeczpospolita” i „Gazeta Wyborcza”) w okresie bezpośrednio następującym po zamachach terrorystycznych w Brukseli (22.03-10.04.2016) i które zawierały przynajmniej jedno z następujących słów:

\footnotetext{
${ }^{3}$ B. Hoffman, Inside Terrorism, Columbia University Press, New York 2006, s. 173-196.

${ }^{4}$ Brussels explosions: What we know about airport and metro attacks, http://www.bbc.com/ news/world-europe-35869985 [dostęp: 15.06.2016]; F. Karimi, M. Haddad, T. Hume, Brussels terrorists initially planned to attack in France, prosecutor says, http://edition.cnn.com/2016/04/10/ europe/brussels-attack-arrests/index.html?eref=rss_topstories [dostęp: 15.06.2016].

${ }^{5}$ Islamic State claims responsibility for the Brussels attacks, https://www.washingtonpost. com/world/brussels-on-high-alert-after-explosions-at-airport-and-metro-station/2016/03/22/ b5e9f232-f018-11e5-a61f-e9c95c06edca_story.html [dostęp: 15.06.2016]; L. Dearden, Isis claims responsibility for Brussels attacks 'in revenge for Belgium's role fighting militants in Syria and Iraq', http://www.independent.co.uk/news/world/europe/isis-claims-responsibility-for-brussels-attacks-explosions-bombings-at-airport-and-maalbeek-maelbeek-a6946136.html [dostęp: 15.06.2016].

${ }^{6}$ I. Kamiński, Ograniczenia swobody wypowiedzi dopuszczalne w Europejskiej Konwencji Praw Człowieka. Analiza krytyczna, Wolters Kluwer Polska, Warszawa 2010, s. 473-476; I. Dobosz, Prawo i etyka w zawodzie dziennikarza, Wolters Kluwer Polska, Warszawa 2008, s. 15.
} 
terroryzm, zamach, Państwo Islamskie, ISIS. Kryteria analizy spełniły 74 teksty: 36 z „Rzeczpospolitej” i 38 z „Gazety Wyborczej”". W badaniach autor nie brał pod uwagę materiału ilustracyjnego.

Dla zbadania realizacji funkcji primingu autor wykonał analizę ilościową następujących cech: liczba tekstów, ich ekspozycyjność, cykliczność.

Z kolei podczas określania zastosowania funkcji framingu autor posłużył się pięcioma najpopularniejszymi sposobami ramowania wydarzeń relacjonowanych przez media, które wskazał Robert Entman. Autor dokonał weryfikacji następujących hipotez badawczych:

1) $\mathrm{W}$ poddanych analizie dziennikach w okresie od 22.03. do 8.04.2016 zauważa się jednakowy stopień zainteresowania mediów zamachami terrorystycznymi w Brukseli i tematyką terroryzmu albo odnotowuje się zróżnicowany stopień zainteresowania, np. w miarę upływu czasu zmniejsza się ekspozycyjność tematów dotyczących terroryzmu, spada liczba artykułów związanych z tą problematyką - pojawiają się rzadziej i zajmują mniejszą objętość.

2) Kryteria oceny organizacji terrorystycznej Państwo Islamskie ustanawiane przez autorów poddanych analizie tekstów prasowych mają swoje odniesienie do podstawowych praw człowieka albo nie mają takiego odniesienia.

3) W kształtowaniu wizerunku medialnego ISIS podstawowym sposobem ramowania wydarzeń relacjonowanych przez media jest jedno z następujących: konflikt, historia ludzka, konsekwencje, kwestia moralna lub odpowiedzialność.

\section{Realizacja funkcji torowania (priming) w kontekście aktów terrorystycznych w Brukseli}

W niniejszym artykule przez funkcję torowania (priming) autor rozumie używanie przez odbiorców mediów kryteriów, standardów służących do oceny rzeczywistości politycznej, których rolę pełnią kwestie najbardziej dostępne w mediach ${ }^{8}$. Dostępność w prasie wyraża się m.in. w liczbie tekstów dotyczących badanej kwestii, ich ekspozycyjności, a także cykliczności, czyli powtarzania się z określonym nasileniem danej cechy. Stopień realizacji funkcji torowania $\mathrm{w}$ odniesieniu do zamachów terrorystycznych $\mathrm{w}$ Brukseli w analizowanych tytułach prasowych wyraził się zatem w badaniach empirycznych. Autor przedstawił dane liczbowe tekstów, które w badanym okresie ukazały

\footnotetext{
${ }^{7}$ Pełny wykaz tekstów prasowych spełniających kryteria metodologiczne znajduje się w bibliografii.

${ }^{8}$ E. Nowak, Koncepcja primingu w studiach nad komunikowaniem politycznym, „Studia Medioznawcze" 2012, nr 2 (49), s. 117, http://sm.id.uw.edu.pl/Numery/2012_2_49/pelny.pdf [dostęp: 15.06.2016].
} 
się w prasie. Określił ponadto miejsce (numer strony), w którym podjęto temat terroryzmu, a także to, czy zagadnienie terroryzmu zostało poruszone tylko w pierwszych dniach po zamachach w Brukseli (23-31.03.2016) czy może publikacje na ten temat zajmowały również znaczące miejsce w okresie nieco późniejszym (1-8.04.2016).

Medioznawcy zwracają uwagę, że efekt primingu wyraża się w ustanawianiu przez autorów tekstów prasowych kryteriów oceny kwestii i osób politycznych ${ }^{9}$. W analizowanym przypadku chodzi o kryteria oceny dotyczące podejmowanych działań przez organizację terrorystyczną Państwo Islamskie i popełnionych przez nie zamachów oraz o kryteria postępowania przywódców krajów europejskich $\mathrm{i}$ ich rolę w zwalczaniu ISIS. W artykule autor podjął próbę zweryfikowania, czy podstawowe prawa człowieka, o których mowa w Powszechnej Deklaracji Praw Człowieka z 10 grudnia 1948 roku, zostały zaprezentowane w analizowanych tekstach prasowych jako kryteria oceny kwestii i osób politycznych, w tym organizacji terrorystycznych. „Podstawowe prawa człowieka” to: prawo do wolności i równości pod względem swej godności i praw ${ }^{10}$, niezależnie od rasy, koloru, płci, języka, wyznania, poglądów politycznych, narodowości, pochodzenia społecznego, majątku, urodzenia ${ }^{11}$; prawo do życia, wolności i bezpieczeństwa swej osoby $^{12}$, a także zakaz torturowania, karania lub traktowania w sposób okrutny, nieludzki lub poniżający ${ }^{13}$.

Celem analizy ilościowej jest odpowiedź na pytanie, w jaki sposób została zrealizowana funkcja priming $u \mathrm{w}$ kontekście relacjonowania aktów terrorystycznych w Brukseli przez dwa najważniejsze ogólnopolskie dzienniki. W tabeli 1 zaprezentowane zostały dane dotyczące liczby tekstów, które ukazały się w poszczególnych numerach „Rzeczpospolitej” i „Gazety Wyborczej”.

Tabela 1. Liczba tekstów prasowych w kolejnych numerach „Rzeczpospolitej” i „Gazety Wyborczej”

\begin{tabular}{|c|c|c|c|c|c|c|c|c|c|c|c|c|c|c|c|}
\hline & $\begin{array}{l}\text { ô } \\
\text { ते }\end{array}$ & $\begin{array}{l}\text { ô } \\
\ddot{v}\end{array}$ & $\begin{array}{l}\dot{\delta} \\
\dot{j} \\
\dot{v}\end{array}$ & $\begin{array}{l}m \\
\dot{n} \\
\vec{v}\end{array}$ & $\begin{array}{l}\dot{0} \\
\infty \\
\infty \\
\hat{N} \\
\stackrel{\nu}{N}\end{array}$ & $\begin{array}{l}\text { ঠ் } \\
\stackrel{\lambda}{ }\end{array}$ & $\begin{array}{l}\dot{0} \\
\dot{0} \\
\dot{m}\end{array}$ & $\frac{\dot{\theta}}{\dot{m}}$ & $\stackrel{\leftrightarrow}{\stackrel{D}{0}}$ & $\begin{array}{l}\dot{D} \\
\dot{D} \\
\sim\end{array}$ & $\begin{array}{l}\dot{\dot{O}} \\
\dot{\nabla}\end{array}$ & $\begin{array}{l}\dot{\Delta} \\
\dot{0}\end{array}$ & 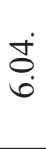 & 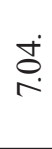 & $\underset{\infty}{\dot{D}}$ \\
\hline „Rzeczpospolita” & 1 & 9 & 9 & 8 & 2 & 3 & 0 & 0 & 2 & 0 & 2 & 0 & 0 & 0 & 0 \\
\hline "Gazeta Wyborcza” & 0 & 9 & 7 & 4 & 7 & 2 & 1 & 2 & 2 & 3 & 0 & 0 & 0 & 1 & 0 \\
\hline
\end{tabular}

Źródło: oprac. własne.

\footnotetext{
${ }^{9}$ Tamże.

${ }^{10}$ Powszechna Deklaracja Praw Człowieka, 10.12.1948, art. 1.

${ }^{11}$ Tamże, art. 2.

12 Tamże, art. 3.

${ }^{13}$ Tamże, art. 5.
} 
Z analizy danych wynika, że w pierwszych trzech dniach po zamachach terrorystycznych w Brukseli (23-28.03.2016) liczba publikacji utrzymywała się na stałym, wysokim poziomie: w „Rzeczpospolitej” ukazało się 28 artykułów, w „Gazecie Wyborczej” zaś 27 - łącznie 55, co daje średnią 6,87 teksu dotyczącego tych wydarzeń w jednym numerze dziennika. Upływ czasu ujawnił postępujący spadek zainteresowania dziennikarzy problematyką terroryzmu. W okresie 29.03-4.04.2016 w ,Rzeczpospolitej” ukazało się 7 tekstów, w „Gazecie Wyborczej” zaś 10 - razem 17, co daje średnią 1,41 artykułu na temat terroryzmu w jednym numerze pisma. $Z$ kolei pomiędzy 5.04. a 8.04.2016, czyli łącznie w ośmiu analizowanych numerach, ukazała się tylko jedna publikacja na temat terroryzmu, co dało średnią 0,125 . Ogółem w okresie pomiędzy 22.03. a 8.04. opublikowano 74 artykuły prasowe w 30 numerach „Rzeczpospolitej” ' „,Gazety Wyborczej”, co dało średnią 2,46 dla tekstów spełniających kryteria metodologiczne obecności tematu w jednym numerze dziennika.

Otrzymane wyniki nie powinny zdumiewać, bo największe zainteresowanie opinii publicznej newsem ma miejsce tuż po jego zaistnieniu, natomiast z upływem czasu ,efekt świeżości” znika, maleje siła oddziaływania danego zdarzenia na media i pojawiają się nowe informacje, wypierające starsze $\mathrm{z}$ agendy medialnej na bardziej odległe miejsce lub w ogóle poza agendę.

W podjętym badaniu zostały wyróżnione trzy kategorie ekspozycyjności (tj. miejsca pojawienia się tekstu prasowego w dzienniku): I stopnia - w przypadku, gdy teksty ukazują się na jedynce, II stopnia - gdy teksty ukazują się na drugiej lub trzeciej kolumnie, III stopnia - jeżeli ukazują się na kolejnych stronach. Teksty z ekspozycyjnością I stopnia uważane są za najważniejsze, a z ekspozycyjnością III stopnia za najmniej istotne.

Badania pod kątem ekspozycyjności przedstawia tabela 2, która prezentuje łączną liczbę artykułów przyporządkowanych do wyżej wymienionych kategorii ekspozycyjności w okresie 22.03-8.04.2016.

Tabela 2. Liczba tekstów prasowych w „Rzeczpospolitej” i „Gazecie Wyborczej” przyporządkowana do kategorii „ekspozycyjność”

\begin{tabular}{|l|c|c|c|}
\hline & $\begin{array}{c}\text { Ekspozycyjność } \\
\text { I stopnia }\end{array}$ & $\begin{array}{c}\text { Ekspozycyjność } \\
\text { II stopnia }\end{array}$ & $\begin{array}{c}\text { Ekspozycyjność } \\
\text { III stopnia }\end{array}$ \\
\hline „Rzeczpospolita” & 3 & 10 & 23 \\
\hline „Gazeta Wyborcza" & 2 & 2 & 34 \\
\hline Ogółem & 5 & 12 & 57 \\
\hline
\end{tabular}

Źródło: oprac. własne.

Spośród wszystkich analizowanych tekstów spełniających kryteria metodologiczne dominowały teksty o III stopniu ekspozycyjności, których było w sumie 57, co stanowi 77,02\% wszystkich tekstów spełniających kryteria analizy. Godny uwagi jest fakt 
podjęcia tematu terroryzmu na pierwszej stronie numeru aż w pięciu przypadkach (trzy w „Rzeczpospolitej”, dwa w „Gazecie Wyborczej”). Teksty o I stopniu ekspozycyjności ukazały się w czterech przypadkach bezpośrednio po zamachach terrorystycznych, 23.03. i 24.04., a w jednym przypadku 4.04. ${ }^{14} \mathrm{Z}$ kolei aż dziesięć spośród dwunastu tekstów o ekspozycyjności II stopnia ukazało się w trzech pierwszych dniach po dokonanych aktach terrorystycznych w Brukseli, czyli pomiędzy 23.03. a 5.03.2016 ${ }^{15}$. W okresie 26.03-8.04.2016 w analizowanych tytułach prasowych ukazały się tylko dwa spośród dwunastu tekstów o II stopniu ekspozycyjności, co ukazuje spadek zainteresowania mediów tematyką zamachów w Brukseli w dalszej perspektywie ${ }^{16}$.

Istnieją różnice pomiędzy analizowanymi dziennikami wyrażające się w liczbie artykułów o II stopniu ekspozycyjności: w „Rzeczpospolitej” jest ich dziesięć, w „Gazecie Wyborczej” - dwa. Biorąc pod uwagę te dane, można stwierdzić, że temat zamachów terrorystycznych w Brukseli częściej zajmował bardziej eksponowane miejsca w dzienniku „Rzeczpospolita”.

Z kolei porównując liczbę tekstów o III stopniu ekspozycyjności, które ukazały się w okresie bezpośrednio następującym po zamachach i w dalszej perspektywie, otrzymujemy następujący wynik: łącznie w „Rzeczpospolitej” i „Gazecie Wyborczej” w dniach 23-31.03. ukazało się 49 tekstów o III stopniu ekspozycyjności, a pomiędzy 1.04. a 8.04. jedynie 8 tekstów należących do tej kategorii.

W badanej cesze „objętość” autor rozróżnia cztery kategorie tekstów: bardzo duże (zajmujące powierzchnię przynajmniej dwóch stron); duże (mające powierzchnię przynajmniej jednej strony, ale mniejsze niż dwie strony); średnie (ich powierzchnia jest nie mniejsza niż pół strony, ale mniejsza niż jedna strona); małe (powierzchnia poniżej pół strony). Kategorie te odnoszą się do stronic gazet, czyli zadrukowanych kolumn. Wyniki badania pod kątem objętości zawiera tabela 3, która prezentuje łączną liczbę tekstów przyporządkowanych do wyżej wymienionych kategorii w okresie 22.03-8.04.2016.

Tabela 3. Liczba tekstów prasowych w „Rzeczpospolitej” i „Gazecie Wyborczej” przyporządkowana do kategorii „objętość”

\begin{tabular}{|l|c|c|c|c|}
\hline & $\begin{array}{c}\text { Teksty } \\
\text { bardzo duże }\end{array}$ & $\begin{array}{c}\text { Teksty } \\
\text { duże }\end{array}$ & $\begin{array}{c}\text { Teksty } \\
\text { średnie }\end{array}$ & $\begin{array}{c}\text { Teksty } \\
\text { małe }\end{array}$ \\
\hline „Rzeczpospolita” & 0 & 2 & 13 & 21 \\
\hline „Gazeta Wyborcza” & 1 & 6 & 14 & 17 \\
\hline Ogółem & 1 & 8 & 27 & 38 \\
\hline
\end{tabular}

Źródło: oprac. własne.

\footnotetext{
${ }^{14}$ Zob. bibliografia analizowanych tekstów na końcu artykułu.

${ }^{15}$ Zob. bibliografia analizowanych tekstów na końcu artykułu.

${ }^{16}$ Zob. bibliografia analizowanych tekstów na końcu artykułu.
} 
Przeprowadzona analiza dowiodła, że teksty spełniające kryteria badania są zasadniczo tekstami małymi i średnimi. Łącznie wyróżniono 27 tekstów średnich oraz 38 małych, co stanowi 87,83\% wszystkich artykułów.

Godne uwagi jest to, że w „Gazecie Wyborczej” w opisywanym okresie autor odnalazł łącznie siedem tekstów bardzo dużych i dużych, natomiast w „Rzeczpospolitej” jedynie dwa należące do tych kategorii. To może wskazywać na bardziej dokładną, pogłębioną analizę tematów dokonywaną przez dziennikarzy „Gazety Wyborczej”.

Spośród 74 rozpatrywanych tekstów prasowych w 26 (16 w „Rzeczpospolitej”, $10 \mathrm{w}$ „Gazecie Wyborczej”) odniesiono się do podstawowych praw człowieka jako kryterium oceny działalności osób zaangażowanych $w$ walkę z terroryzmem lub oceny działań organizacji terrorystycznych. Oto wybrane przykłady tekstów prasowych ukazujące ich odniesienie do podstawowych praw człowieka:

- „Po krwawych zamachach w Brukseli rosyjscy politycy po raz kolejny powrócili do debaty na temat kary głównej” (R. Szoszyn, Rosja: wróciła dyskusja o przywróceniu kary śmierci, „Rzeczpospolita” 2016, 25.03, s. A8).

- „To, co legalne i uzasadnione prawnie, staje się moralne, a jeśli ktoś to kwestionuje w imię prawa naturalnego, jest katolickim bigotem. Tyle że jeśli odrzucić zasady prawa naturalnego i uznać, iż jedynymi zasadami, jakie nas obowiązują, są te ustanowione przez prawodawców, to nie ma jak potępić islamskich terrorystów. Według ich zasad zabijanie niewiernych - jeśli toczy się święta wojna - jest uzasadnione. A skoro wszystkie systemy etyczne, religie i cywilizacje są równe, to jak tu uznać, że system moralny i religijny, który pozwala na zabijanie niewinnych ludzi, jest gorszy od naszego?” (T. Terlikowski, Na drodze do Kalifatu Europa, „Rzeczpospolita Plus Minus" 2016, 26.03, s. 34).

- „W Niemczech, gdzie mieszka ponad 3 mln osób pochodzenia tureckiego, obserwuje się wydarzenia nad Bosforem wyjątkowo uważnie. Nie brak głosów, że rządzona przez Erdogana Turcja oddala się w szybkim tempie od standardów europejskich w takich sprawach, jak swobody obywatelskie czy wolność prasy. Mnożą się obawy, że Turcja nie dotrzyma warunków umowy z UE w sprawie przyjmowania nielegalnych imigrantów, zatrzymanych w Europie" (P. Jendroszczyk, Erdogan poucza Niemcy, „Rzeczpospolita” 2016, 1.04, s. A10).

\section{Realizacja funkcji uramowienia (framing) w kontekście aktów terrorystycznych w Brukseli}

Framing oznacza wybór oraz wyeksponowanie pewnych aspektów lub kwestii i powiązanie ich w taki sposób, żeby promowały określoną interpretację, ocenę 
czy rozwiązanie ${ }^{17}$. Określone aspekty rzeczywistości są zatem w pierwszej kolejności postrzegane przez dziennikarzy, a następnie akcentowane i uwypuklane $\mathrm{w}$ artykułach, co z kolei prowadzi do określonej interpretacji i moralnej ich oceny oraz do faworyzowania danego tematu ${ }^{18}$. Framing umożliwia redukcję kompleksowości tematów i wydarzeń, sprowadzając je jedynie do wybranych aspektów. Technika ramowania daje pewne uproszczenia, ale jednocześnie wzory interpretacji i wzory rozumienia pewnych treści ${ }^{19}$. W analizie jakościowej publikacji prasowych na temat aktów terrorystycznych w Brukseli autor dokonał kategoryzacji materiału, posługując się zaproponowanymi przez Entmana najpopularniejszymi ramami interpretacyjnymi, wykorzystywanymi przez media: wydarzenie jako konflikt, wydarzenie jako historia ludzka, wydarzenie jako konsekwencje, wydarzenie jako kwestia moralna, wydarzenie jako odpowiedzialność ${ }^{20}$. W tekstach prasowych autor wskazał zatem jedną lub dwie podstawowe ramy, w jakich zostały zaprezentowane wydarzenia i wyróżnił następujące kategorie:

- ataki terrorystyczne w Brukseli jako konflikt (relacje medialne skupiają się na niezgodzie, podziale, różnicach, rywalizacji);

- ataki terrorystyczne w Brukseli jako historia ludzka (bohaterami relacji medialnych są indywidualne ofiary, wymieniane także z imienia i nazwiska; personalizacja odnosi się również do odpowiedzialnych za zamach; większe znaczenie przypisuje się jednostce niż faktom czy liczbom);

- konsekwencje zamachów (autorzy tekstów prasowych przedstawiają konsekwencje, „które mogą wystąpić w różnych obszarach życia społecznego, np. w ekonomii i na różnych poziomach (na poziomie lokalnym, narodowym, globalnym);

- ataki terrorystyczne jako kwestia moralna (autorzy tekstów posługują się kategoriami dobra i zła moralnego);

- ataki terrorystyczne jako odpowiedzialność (autorzy tekstów prasowych obarczają winą za dokonane zamachy kogoś lub coś).

W tabeli nr 4 autor zestawił liczbę tekstów przyporządkowanych do poszczególnych ram interpretacyjnych w ujęciu Entmana (zgodnie z przyjętą metodologią jeden tekst mógł być przyporządkowany do jednej lub dwóch ram).

${ }^{17}$ R. Entman, Cascading Activation: Contesting the White House's Frame After 9/11, „Political Communication" 2003, Vol. 20, Issue 4, p. 417, za: D. Piontek, Komunikowanie polityczne i kultura popularna. Tabloidyzacja informacji o polityce, Wydawnictwo Naukowe WNPiD UAM, Poznań 2011, s. 71.

${ }^{18}$ R. Entman, Framing. Toward clarification of a fractured paradigm, „Journal of Communication" 1993, No. 4, s. 51-58, za: S. Michalczyk, Jednostka i społeczeństwo w świecie mediów. Klasyczne i wspótczesne idee w teoriach średniego zasięgu, Stowarzyszenie Thesaurus Silesiae - Skarb Śląski. „Śląsk” Wydawnictwo Naukowe, Katowice 2015, s. 79.

${ }^{19}$ S. Michalczyk, dz. cyt., s. 79.

${ }^{20}$ D. Piontek, dz. cyt., s. 73. 
Tabela 4. Obecność ram interpretacyjnych w analizowanych tekstach prasowych „Rzeczpospolitej” i „Gazecie Wyborczej”

\begin{tabular}{|l|c|c|c|c|c|}
\hline & Konflikt & $\begin{array}{c}\text { Historia } \\
\text { ludzka }\end{array}$ & $\begin{array}{c}\text { Konse- } \\
\text { kwencje }\end{array}$ & $\begin{array}{c}\text { Kwestia } \\
\text { moralna }\end{array}$ & $\begin{array}{c}\text { Odpowie- } \\
\text { dzialność }\end{array}$ \\
\hline „Rzeczpospolita” & 7 & 7 & 29 & 3 & 4 \\
\hline „Gazeta Wyborcza” & 12 & 9 & 22 & 3 & 2 \\
\hline Ogółem & 19 & 16 & 51 & 6 & 6 \\
\hline
\end{tabular}

Źródło: oprac. własne.

Dominującym sposobem interpretacji jest ujęcie zamachów terrorystycznych w kategorii konsekwencji - ten sposób występował jako jeden z przeważających aż w 51 tekstach.

Najliczniej reprezentowany sposób ramowania wydarzeń, tj. postrzegany jako źródło konsekwencji w życiu społecznym i politycznym, zauważalny jest m.in. w następujących tekstach prasowych:

- „Dla przeciwników Unii w Wlk. Brytanii atak na Brukselę może się stać kolejnym dowodem jej słabości, tego, że nie potrafi obronić swoich członków przed niebezpieczeństwem. I po populistycznej «obróbce» w kampanii referendalnej - następnym powodem do tego, by głosować za Brexitem” (T. Bielecki, Terror w Brukseli, „Gazeta Wyborcza" 2016, 23.03, s. 1).

- „Ataki w Brukseli nastąpiły w trudnym dla Europy momencie. Zawarła właśnie porozumienie z Turcją, które ma zatrzymać falę uchodźców płynących do UE i ocalić strefę Schengen. Jednak ruch bez kontroli granicznej jest coraz większym problemem. Nic więc dziwnego, że po zamachu Francja, Holandia i Niemcy zapowiedziały wzmożone kontrole. Trudniej też będzie przekonać społeczeństwa do przyjmowania uchodźców. Wreszcie atak w Brukseli to paliwo dla populistycznych partii w Europie, których hasłem jest zamknięcie granic dla imigrantów, a przy okazji zniesienie strefy Schengen. Jest też ciosem dla brytyjskiego premiera Davida Camerona, który w referendum zapowiedzianym na 23 czerwca chciał przekonać rodaków, że bezpieczniej jest pozostać w Unii Europejskiej" (A. Słojewska, Atak w sercu Europy, „Rzeczpospolita” 2016, 23.03, s. A1).

Autorzy artykułów prasowych dość często posługiwali się również ramą konfliktu (w 19 przypadkach) oraz ramą historii ludzkiej (w 16 przypadkach). Rama konfliktu jest dostrzegalna m.in. w następujących tekstach:

- „Mieszkańcy Brukseli, którzy przywykli do wielotygodniowych alertów terrorystycznych, jakby nie dowierzali, że tym razem to wydarzyło się naprawdę" (T. Bielecki, Eksplozja w stolicy Europy, „Gazeta Wyborcza” 2016, 23.03, s. 14). 
- „Wiele wskazuje na to, że wtorkowy atak na Brukselę to kolejny etap scenariusza zastraszania Zachodu przez tzw. Państwo Islamskie. $Z$ jego poprzednimi odcinkami mieliśmy do czynienia między innymi w Paryżu, Kopenhadze, a także w odwiedzanych przez turystów zachodnich miastach świata islamu. Wykonawcy byli młodzi, zazwyczaj zradykalizowali się niedawno, a na organizację zamachu musieli wydać niewielkie sumy" (J. Haszczyński, Załóżmy, że nie jest za późno na pokonanie dżihadystów, „Rzeczpospolita” 2016, 23.03, s. A2).

Ataki terrorystyczne w Brukseli ukazywane jako historia ludzka można dostrzec m.in. w następujących artykułach prasowych:

- „Bracia Salah i Brahim Abdeslamowie, a także Bilal Hadfi i Abdelhamid Abaaoud, którzy dokonali w listopadzie ataków w Paryżu, urodzili się i wychowali w Belgii. Terroryści, którzy zaatakowali redakcję «Charlie Hebdo» w styczniu 2015 r., mieli się zaopatrzyć w broń w Belgii. Podobnie jak Ayoub el-Khazzani, który próbował dokonać ataku w pociągu z Amsterdamu do Paryża w ubiegłym roku" ([MORE], Dżihadyści z belgijskim rodowodem, „Gazeta Wyborcza” 2016, 23.03, s. 15).

- „Belgijska prokuratura od soboty przesłuchuje Saleha Abdeslama, podejrzewanego o zorganizowanie ataków terrorystycznych na Paryż 13 listopada 2015 roku, a przynajmniej o istotny w nich udział. W atakach tych zginęło 130 osób" (A. Słojewska, Paryski terrorysta zeznaje w Belgii, „Rzeczpospolita” 2016, 22.03, s. A8).

Rama moralna i rama odpowiedzialności stanowiły dwie ramy interpretacyjne, które najrzadziej pojawiały się w analizowanych tekstach prasowych.

Do tekstów prasowych ukazujących akt terrorystyczny jako kwestię moralną można zaliczyć m.in. następujące:

- „Przywódcy radykalnych ugrupowań często stosują nienawiść i przemoc instrumentalnie - aby prowokować władze do inwigilacji i opresji wobec mniejszości. To radykałom na rękę, bo napędza poczucie odrzucenia (czemu jestem ciągle kontrolowany we własnym kraju?) i staje się siłą napędową dezidentyfikacji, alienacji, a ta ułatwia werbowanie na śmierć” (M. Rolecki, Kto zostaje terrorysta?, „Gazeta Wyborcza" 2016, 1.04, s. 18).

- „Ci młodzi ludzie powołują się na słowa proroka, na wersety Koranu. W szczególności na surę 9., werset 5., w którym w niezwykle brutalny sposób każe się wiernym nienawidzić niewiernych, eksterminować ich. Ja wtedy staram się tłumaczyć, że w Koranie jest wiele sprzeczności, że nawet w samej surze 9., pod koniec wersetu 7. Jest mowa o tym, że nie wolno zabijać kogoś, kto wobec nas zachowuje się sprawiedliwie" (J. Bielecki, Spotkatem wielu dżhadystów [wywiad z Mohamed Galaye Ndiaye], ,Rzeczpospolita” 2016, 23.03, s. A4-A5). 
Z kolei ujmowanie zamachów terrorystycznych w kategoriach odpowiedzialności obecne jest w następujących tekstach:

- „Służby specjalne w całej Europie szukają konstruktora bomb, które wybuchły w Brukseli. Zawierały nadtlenek acetonu, silny materiał wybuchowy, który terroryści od dawna produkują w domach” (B. Wieliński, Zabójcza matka szatana, „Gazeta Wyborcza" 2016, 24.03, s. 12).

- „Prawdopodobnie ta zbrodnia była odwetem za pojmanie Salaha Abdeslama. Chociaż odpowiedzialność za zamach bierze na siebie kalifat Państwa Islamskiego, to metoda przypomina terroryzm Al-Kaidy. Uśpiona komórka uderza na sygnał w reakcji na przewidywane wydarzenie" (J. Nizinkiewicz, Europa wyrzekła się tożsamości [wywiad z Markiem Jurkiem], „Rzeczpospolita” 2016, 25.03, s. A4).

W kwestii proporcji występowania poszczególnych ram interpretacyjnych nie dostrzega się różnic pomiędzy dziennikami „Rzeczpospolita” i „Gazeta Wyborcza”.

\section{Wnioski}

Po przeprowadzonej analizie autor zweryfikował postawione hipotezy badawcze. W wydaniach papierowych „Rzeczpospolitej” i „Gazety Wyborczej” w okresie 22.03-8.04.2016 odnotowuje się zróżnicowany stopień zainteresowania mediów zamachami w Brukseli i tematyką terroryzmu. Największe zainteresowanie środków masowego przekazu badaną tematyką ma miejsce w czasie bezpośrednio następującym po atakach, następnie systematycznie spada aż do całkowitego zaniku. W poddanych analizie dziennikach odnotowuje się zbliżoną liczbę tekstów dotyczących zamachów terrorystycznych, temat ten zajmuje bardziej eksponowane miejsca w „Rzeczpospolitej”. Kryteria oceny organizacji terrorystycznej Państwo Islamskie ustanawiane przez autorów publikacji mają swoje odniesienie do podstawowych praw człowieka, można było to dostrzec aż w 26 tekstach. W kształtowaniu wizerunku medialnego ISIS podstawowym sposobem ramowania wydarzeń jest rama konsekwencji.

Przeprowadzona analiza ukazuje ważną rolę aktów terrorystycznych w kształtowaniu agendy medialnej. Priming i framing wpływają z kolei na sposób odbioru Państwa Islamskiego i zamachów w Brukseli. Prawa człowieka są ważnym standardem służącym do oceny działań ISIS, kwestia ta była obecna $\mathrm{w}$ badanych tekstach. Materiał zasadniczo oferuje szeroką panoramę w sposobie interpretowania dramatycznych wydarzeń z 22 marca 2016 roku. W niejednakowym stopniu, ale jednak, wszystkie sposoby kategoryzowania wydarzenia w ujęciu Entmana zostały przez autora odnotowane. 
Należy zadać pytanie o proporcję materiału badawczego na temat dramatycznych wydarzeń z Brukseli w kontekście działań organizacji terrorystycznej ISIS. Z pewnością polskie dzienniki zaoferowały opinii publicznej wnikliwą analizę kwestii, podpartą opiniami ekspertów (np. Anthony’ego Dworkina z European Council for Foreign Relations; Michaëla Dantinna, kryminologa i eksperta ds. terroryzmu z Uniwersytetu z Liège; Konrada Pędziwiatra, adiunkta w Katedrze Studiów Europejskich Uniwersytetu Ekonomicznego w Krakowie; Edwina Bakkera, dyrektora Instytutu ds. Bezpieczeństwa i Spraw Globalnych Uniwersytetu w Lejdzie w Holandii; Iwana Krastewa, szefa Centrum Strategii Liberalnych w Sofii) czy relacjami naocznych świadków - korespondentów (np. Tomasza Bieleckiego, Anny Słojewskiej). Media nie przemilczały tematu brukselskiej tragedii. Podjęta analiza ukazała znaczącą liczbę informacji prasowych na temat zamachów brukselskich. Wskazana w badaniach liczba tekstów, ich objętość i ekspozycyjność potwierdzają tezę o ważnej roli aktów terrorystycznych w kształtowaniu agendy medialnej. „Rzeczpospolita” i „Gazeta Wyborcza" o zamachu w Brukseli pisały bardzo obszernie w pierwszych dniach po wydarzeniu, a w miarę upływu czasu wydarzenie to przesłoniły inne, świeższe informacje. Ma rację Kazimierz Wolny-Zmorzyński, twierdząc, że „gdy głośno o jednym wydarzeniu, wszyscy o nim piszą. Nadchodzi nowa sensacja, do wcześniejszych prawie każdy z reporterów już nie wraca i idą one w cień tych najświeższych"21. W przekonaniu autora niniejszego tekstu ta praktyka dziennikarska wobec relacjonowania zamachów terrorystycznych tworzy pewnego rodzaju „dyktaturę mediów”. Społeczeństwo interesuje się tym, czym jest „karmione” przez środki masowego przekazu: relacjonowanymi newsami, komentarzami, opiniami, fotografiami. Taki też tworzy sobie obraz rzeczywistości. Zniknięcie po kilku dniach z agendy medialnej tematu zamachu brukselskiego nie oznacza rozwiązania kwestii działalności islamskich organizacji terrorystycznych na terenie Europy. Problem pozostaje, media przestają o nim mówić, podejmują inne tematy. Wydaje się zatem słuszny postulat przestrzegania właściwych proporcji w przekazywaniu informacji przez media: by dobrze wypełniły one misję informacyjną, nie tworząc jednocześnie darmowej reklamy organizacjom terrorystycznym poprzez kreowanie kultury strachu czy poczucia zagrożenia przed nimi, co może pomagać im w osiąganiu swych celów.

\section{Bibliografia}

\section{Analizowane teksty prasowe}

Bielecki J., Daesh atakuje Europę [wywiad z Érikiem Denécé], „Rzeczpospolita” 2016, 23.03, s. A3. Bielecki J., Dżihadyści niszcza jedność Europy, „Rzeczpospolita” 2016, 24.03, s. A1.

${ }^{21}$ K. Wolny-Zmorzyński, Ryszard Kapuściński w labiryncie współczesności, Wydawnictwo Uniwersytetu Jagiellońskiego, Kraków 2004, s. 45. 
Bielecki J., Spotkałem wielu dżihadystów [wywiad z Mohamedem Galaye Ndiaye], „Rzeczpospolita", 23.03, s. A4-A5.

Bielecki T., Eksplozja w stolicy Europy, „Gazeta Wyborcza” 2016, 23.03, s. 14.

Bielecki T., Terror w Brukseli, „Gazeta Wyborcza” 2016, 23.03, s. 1.

Biernacki M., Opinia, „Rzeczpospolita” 2016, 25.03, s. A3.

Gajcy A., CIA ostrzega, rzad się nie boi, „Rzeczpospolita” 2016, 4.04, s. A3.

Gajcy A., Czy rzad lekceważy terrorystów, „Rzeczpospolita” 2016, 4.04, s. A1.

Haszczyński J., Uchodźcy czekają na swoich sprawiedliwych, „Rzeczpospolita” 2016, 24.03, s. A2.

Haszczyński J., Załóżmy, że nie jest za późno na pokonanie dżihadystów, „Rzeczpospolita” 2016, 23.03, s. A2.

Imielski R., Ta wojna szybko się nie skończy, „Gazeta Wyborcza” 2016, 23.03, s. 2.

Jałoszewski M., Kondzińska A., Agencja bierze wszystko, „Gazeta Wyborcza” 2016, 24.03, s. 1.

Jendroszczyk P., Erdogan poucza Niemcy, „Rzeczpospolita” 2016, 1.04, s. A10.

Kacprzak I., Zawadka G., Przepis na walke z terrorem, „Rzeczpospolita” 2016, 25.03, s. A3.

[MORE], Dżihadyśsi z belgijskim rodowodem, „Gazeta Wyborcza” 2016, 23.03, s. 15.

Nizinkiewicz J., Europa wyrzekła się tożsamości [wywiad z Markiem Jurkiem], „Rzeczpospolita” 2016, 25.03, s. A4.

Pietrzak M., Opinia, „Rzeczpospolita” 2016, 25.03, s. A3.

Rolecki M., Kto zostaje terrorysta?, „Gazeta Wyborcza” 2016, 1.04, s. 18.

Słojewska A., Atak w sercu Europy, „Rzeczpospolita” 2016, 23.03, s. A1.

Słojewska A., Paryski terrorysta zeznaje w Belgii, „Rzeczpospolita” 2016, 22.03, s. A8.

Stankiewicz A., Paragrafy na terroryzm to za mało, „Rzeczpospolita” 2016, 25.03, s. A2.

Stanisławski W., Kredki dla Mogherini, „Rzeczpospolita” 2016, 24.03, s. A2.

Szoszyn R., Rosja: wróciła dyskusja o przywróceniu kary śmierci, „Rzeczpospolita” 2016, 25.03, s. A8.

Terlikowski T., Na drodze do Kalifatu Europa, „Rzeczpospolita Plus Minus”, 26.03, s. 34.

Wieliński B., Tylko więcej Unii nas uratuje, „Gazeta Wyborcza” 2016, 26-28.03, s. 2.

Wieliński B., Zabójcza matka szatana, „Gazeta Wyborcza” 2016, 24.03, s. 12.

Zawadka G., Polacy w sondażu: nie otwierajmy granic dla uchodźców, „Rzeczpospolita” 2016, 25.03, s. A3.

\section{Pozostałe teksty prasowe spelniające kryteria metodologiczne}

Applebaum A., Izolacjonizm to nieszczęście, „Gazeta Wyborcza” 2016, 26-28.03, s. 19.

Bielecki J., Egzystencjalne wyzwanie dla Belgii, „Rzeczpospolita” 2016, 23.03, s. A5.

Bielecki J., Wojna potrwa całe pokolenie, „Rzeczpospolita” 2016, 24.03, s. A6.

Bielecki T., Bruksela tropi terrorystów, „Gazeta Wyborcza” 2016, 24.03, s. 10.

Bielecki T., Dżihadysta szuka domu [wywiad z Didierem Leroyem], „Gazeta Wyborcza” 2016, 2-3.04, s. 8 .

Bielecki T., Gęsta sieć dżihadu we Francji i Belgii. Specslużby zaskoczone, „Gazeta Wyborcza” 2016, 29.03, s. 8 .

Bielecki T., Hollande przegrat konstytucje, „Gazeta Wyborcza” 2016, 31.03, s. 13.

Bielecki T., Obława w Brukseli, „Gazeta Wyborcza” 2016, 26-28.03, s. 12.

Bielecki T., Unia radzi o bezpieczeństwie, „Gazeta Wyborcza” 2016, 25.03, s. 11.

Bryła E., Jaka cena za bezpieczeństwo na lotniskach?, „Gazeta Wyborcza” 2016, 24.03, s. 12.

Czarnecki M., Londyńskie echa zamachów, „Gazeta Wyborcza” 2016, 24.03, s. 12. 
Czarnecki M., Ofensywa przeciw dżihadowi w Syrii i Iraku, „Gazeta Wyborcza” 2016, 25.03, s. 12.

Czarnecki M., Perła pustyni w rękach Asada, „Gazeta Wyborcza” 2016, 29.03, s. 8.

Gajcy A., Kacprzak I., Zawadka G., Przepisy zniechęca przybysza, „Rzeczpospolita” 2016, 24.03, s. A4.

Graczyk R., Musimy rozbić islamskie getta, „Rzeczpospolita Plus Minus”, 2016, 26.03, s. 14.

Jacinto L., Spółdzielnia Dżihad, oddział Bruksela, „Gazeta Wyborcza” 2016, 2-3.04, s. 16.

Jendroszczyk P., Państwo Islamskie w odwrocie, „Rzeczpospolita” 2016, 29.03, s. A10.

Jendroszczyk P., Terror omija Niemcy, „Rzeczpospolita” 2016, 23.03, s. A6.

Jendroszczyk P., Terroryzm zbliża populistów z lewa i prawa, „Rzeczpospolita” 2016, 24.03, s. A6.

Jendroszczyk P., Walcząc z rządem, talibowie morduja chrześcijan, „Rzeczpospolita” 2016, 29.03, s. A10.

Kochanowicz M., Od Lenina do Pol Pota, „Gazeta Wyborcza” 2016, 2-3.04, s. 14-15.

Kondzińska A., Polacy sa bezpieczni - zapewniaja przedstawiciele władz, „Gazeta Wyborcza” 2016, 23.03, s. 16 .

Kondzińska A., Jałoszewski M., Terror wzmacnia tajne służby [wywiad z Barbarą Grabowską-Moroz], „Gazeta Wyborcza” 2016, 1.04, s. 6.

Kościelniak P., Szyfrowanie danych: czy terrorysta ma prawo do prywatności, „Rzeczpospolita” 2016, 23.03, s. A6.

Kozieł H., Zamachy giełdom niestraszne [wywiad z Markiem Buczakiem], „Rzeczpospolita” 2016, 24.03, s. A7.

[LUNA], Zamachy w Europie w 2015 r., „Gazeta Wyborcza” 2016, 23.03, s. 14.

Łomanowski A., Terrorystyczna franczyza w Rosji, „Rzeczpospolita” 2016, 1.04, s. A10.

[MC], Kim byli zamachowcy, „Gazeta Wyborcza” 2016, 24.03, s. 10.

[MC, PAP], Dżihadysta nr 2 nie żyje, „Gazeta Wyborcza” 2016, 26-28.03, s. 11.

Moszyński P., Francja boi się o Euro, „Gazeta Wyborcza” 2016, 26-28.03, s. 12.

Moszyński P., Francja czuje się zagrożona, „Gazeta Wyborcza” 2016, 23.03, s. 15.

Moszyński P., Francuzi „zabezpieczaja” Wielkanoc, „Gazeta Wyborcza” 2016, 25.03, s. 11.

Moszyński P., Paryż zabezpiecza się przed zamachami, „Gazeta Wyborcza” 2016, 24.03, s. 11.

Pędziwiatr K., Dżihadyzm w sercu Europy, „Gazeta Wyborcza” 2016, 25.03, s. 10.

Rębała M., Czy to była zemsta? [wywiad z Michaëlem Dantinnem], „Gazeta Wyborcza” 2016, 23.03, s. 15.

Rębała M., Jak wybić dżihad z głów młodych Francuzów, „Gazeta Wyborcza” 2016, 31.03, s. 13.

Rębała M., Terroryści jawnie ukryci [wywiad z Edwinem Bakkerem], „Gazeta Wyborcza” 2016, 26-28.03, s. 11.

Słojewska A., Ofiar mogło być więcej, „Rzeczpospolita” 2016, 24.03, s. A5.

Słojewska A., Pościg za trzecim terrorysta, „Rzeczpospolita” 2016, 29.03, s. A9.

Słojewska A., Rachunek sumienia Belgii, „Rzeczpospolita” 2016, 25.03, s. A8.

Słojewska A., Terroryści sparaliżowali stolice Belgii, „Rzeczpospolita” 2016, 23.03, s. A4-A5.

Słojewska A., Walka z terroryzmem pozostanie narodowa [wywiad z Anthonym Dworkinem], „Rzeczpospolita” 2016, 24.03, s. A4.

Urazińska A., Maczety na uchodźców, „Gazeta Wyborcza” 2016, 7.04, s. 5.

Walewska D., Firmy licza straty, „Rzeczpospolita” 2016, 24.03, s. A7.

Walewska D., Woźniak A., Rachunek za zamachy, „Rzeczpospolita” 2016, 23.03, s. A6.

Wężyk K., Wojna strachów [wywiad z Iwanem Krastewem], „Gazeta Wyborcza” 2016, 26-28.03, s. $18-19$. 
Wieliński B., Paliwo dla skrajnej prawicy, „Gazeta Wyborcza” 2016, 23.03, s. 16.

Wroński P., Terror i zaufanie, „Gazeta Wyborcza” 2016, 30.03, s. 8.

\section{Pozostale publikacje}

Brussels explosions: What we know about airport and metro attacks, http://www.bbc.com/news/ world-europe-35869985 [dostęp: 15.06.2016].

Dearden L., Isis claims responsibility for Brussels attacks 'in revenge for Belgium's role fighting militants in Syria and Iraq', http://www.independent.co.uk/news/world/europe/isis-claims-responsibility-for-brussels-attacks-explosions-bombings-at-airport-and-maalbeek-maelbeek-a6946136.html [dostęp: 15.06.2016].

Dobosz I., Prawo i etyka w zawodzie dziennikarza, Wolters Kluwer Polska, Warszawa 2008.

Entman R., Cascading Activation: Contesting the White House's Frame After 9/11, „Political Communication" 2003, Vol. 20, Issue 4, pp. 415-432.

Entman R., Framing. Toward clarification of a fractured paradigm, „Journal of Communication” 1993, No. 4, pp. 51-58.

Hoffman B., Inside Terrorism, Columbia University Press, Nowy Jork 2006.

Islamic State claims responsibility for the Brussels attacks, https://www.washingtonpost.com/ world/brussels-on-high-alert-after-explosions-at-airport-and-metro-station/2016/03/22/ b5e9f232-f018-11e5-a61f-e9c95c06edca_story.html [dostęp: 15.06.2016].

Kamiński I., Ograniczenia swobody wypowiedzi dopuszczalne w Europejskiej Konwencji Praw Człowieka. Analiza krytyczna, Wolters Kluwer Polska, Warszawa 2010.

Karimi F., Haddad M., Hume T., Brussels terrorists initially planned to attack in France, prosecutor says, http://edition.cnn.com/2016/04/10/europe/brussels-attack-arrests/index.html?eref=rss_ topstories [dostęp: 15.06.2016].

Laqueur W., The New Terrorism. Fanaticism and the Arms of Mass Destruction, Oxford University Press, New York 2000.

Michalczyk S., Jednostka i społeczeństwo w świecie mediów. Klasyczne i współczesne idee w teoriach średniego zasięgu, Wydawnictwo Naukowe Śląsk, Katowice 2015.

Nowak E., Koncepcja primingu w studiach nad komunikowaniem politycznym, „Studia Medioznawcze” 2012, nr 2 (49), s. 117-128, http://sm.id.uw.edu.pl/Numery/2012_2_49/pelny.pdf [dostęp: 15.06.2016].

Piontek D., Komunikowanie polityczne i kultura popularna. Tabloidyzacja informacji o polityce, Wydawnictwo Naukowe Wydziału Nauk Politycznych i Dziennikarstwa UAM, Poznań 2011.

Powszechna Deklaracja Praw Człowieka, 10.12.1948.

Wolny-Zmorzyński K., Ryszard Kapuściński w labiryncie współczesności, Wydawnictwo Uniwersytetu Jagiellońskiego, Kraków 2004. 


\title{
Rafał Leśniczak \\ Priming and framing of selected Polish publications about the Brussels terror attacks in 2016
}

\begin{abstract}
(Summary)
The purpose of this paper is to define the role of mass media in shaping the image of a terrorist organization on the example of the terrorist bomb attacks carried out on March 22, 2016 in Belgium. The author analyses with particular attention the media with regard to their function of priming and framing in the period immediately following the acts of terror effected in Belgium that have a significant influence on the media image of the terrorist organization Islamic State. The research material is composed of Polish journals "Rzeczpospolita" and "Gazeta Wyborcza" (22.03-8.04.2016). Considering progressive process of mediatization of the public sphere, the author of the paper tries to identify the relationship that exists between the evolution of the image of ISIS and press information.
\end{abstract}

Keywords: mass media, politics, terrorism, dictatorship, image. 